\title{
Pollen Evidence of a Humid Mid-Holocene Climate from Bahar Nuur, Inner Mongolia
}

\author{
Changqing Huang1,2, Lanlan Guo ${ }^{3}$ \\ ${ }^{1}$ Department of Geography and Tourism, Tongren University, Tongren, China \\ ${ }^{2}$ Department of Oceanography and Coastal Sciences, School of the Coast and Environment, Louisiana State University, Baton \\ Rouge, USA \\ ${ }^{3}$ Key Laboratory of Environmental Change and Natural Disaster, Ministry of Education \& State Key Laboratory of Earth Surface \\ Processes and Resource Ecology, Beijing Normal University, Beijing, China \\ Email: 447459502@qq.com
}

How to cite this paper: Huang, C.Q. and Guo, L.L. (2017) Pollen Evidence of a Humid Mid-Holocene Climate from Bahar Nuur, Inner Mongolia. Open Access Library Journal, 4: e3467.

https://doi.org/10.4236/oalib.1103467

Received: February 17, 2017

Accepted: March 28, 2017

Published: March 31, 2017

Copyright $\odot 2017$ by authors and Open Access Library Inc.

This work is licensed under the Creative Commons Attribution International License (CC BY 4.0).

http://creativecommons.org/licenses/by/4.0/

\begin{abstract}
A high-resolution pollen-based bioclimatic reconstruction from Bahar Nuur Lake in Inner Mongolia, China, supported by 15 AMS dates, is compared with other records in the Ordos Plateau and stalagmite record from Dongge cave in order to better understand the Holocene climate history in semi-arid East Asian monsoon margin area better. A humid climate prevailed in the Ordos Plateau during $6.3-4.4 \mathrm{ka} \mathrm{BP}$, as indicated by high broadleaf-tree pollen percentages and pollen concentrations. Due to a strong Asian monsoon, the mid-Holocene climatic optimum exhibited a delayed vegetative response on the Ordos Plateau.
\end{abstract}

\section{Subject Areas}

Atmospheric Sciences

\section{Keywords}

Lake Sediment, Pollen Record, Climate Change, Ordos Plateau, Mid-Holocene

\section{Introduction}

Holocene climate change has been a focus of global change studies because understanding the climatic patterns, processes and forcing mechanisms during this period can shed light upon future climate change and its associated regional ecological responses [1]. To this end, the reconstruction of the temporal patterns of change in climatically sensitive regions is of great importance [2]. The semi-arid East Asian monsoon margin area is one of the regions, most sensitive to largescale climatic changes. However, our knowledge regarding the recent climate his- 
tory in this area is limited. A warm and wet mid-Holocene climate has been widely reported in the East Asian Monsoon-influenced semiarid areas of northern China [3] [4]. However, other researchers suggest a dry mid-Holocene in the south Ordos Plateau based on multi-proxy data [5] [6] [7], while another study from the northwestern edge of the Ordos Plateau suggests extremely dry conditions during 8 - 4 ka BP [8]. More high-resolution records are needed to clarify the Holocene climate history for this important region. In this paper, we shed light on regional changes in climate and vegetation by presenting a new pollen record from the Ordos Plateau.

\section{Study Site}

Our high-resolution pollen record comes from Bahar Nuur $\left(39^{\circ} 19^{\prime} \mathrm{N}, 109^{\circ} 16^{\prime} \mathrm{E}\right.$, $1278 \mathrm{~m}$ a.s.l.), a seasonally dry lake in the middle of the Maowusu Desert on the arid steppe-dominated Ordos Plateau in Inner Mongolia, China. The site is located on the northwestern margin of land affected by the East Asian monsoon and near the outer limit of the summer monsoon (Figure 1). Although cold, dry air masses from the north and west dominate this area for most of the year, the East Asian summer monsoon is bringing abundant precipitation to the area during the summer. The mean annual temperature ranges from $7^{\circ} \mathrm{C}$ to $9^{\circ} \mathrm{C}$ and mean annual precipitation ranges from 200 to $300 \mathrm{~mm}$ [9]. Many lakes occupy wind-deflation or river-eroded depressions formed during the late Quaternary [10]. Bahar Nuur Lake formed along an abandoned river channel that was later modified by sand-dune activities. The dry lakebed occupies an area of 26.50 $\mathrm{kmP}^{2}$, although presently the lake only contains water seasonally.

Following the northwest to the southeast precipitation gradient, vegetation on the Ordos Plateau changes from desert steppe, steppe, to forest steppe from the northwest to the southeast (Figure 1). Specifically, temperate desert, dominated by Chenopodiaceae, occurs in the northwestern most section, whereas temperate Stipa-dominated steppes occur in the southeastern part. The central and southern Ordos Plateau is occupied by temperate Caragana shrubs. Artemisia arenaria and Stipa-dominated steppes are widely distributed throughout the Plateau. Xerophytic plant communities dominated by Agriophyllum squarrosum, Corispermum spp and Salsola spp occupy sandy areas. The modern zonal vegetation around Bahar Nuur is Artemisia arenaria and Stipa-dominated steppes, which also contain Thymus mongolicus, Salsola spp, Astragalus adsurgens, and Ephedra spp [11].

While trees are generally rare in the Bahar Nuur area, conifer and broadleaf mixed forests occur in the mountains to the south, west, and north of the study site. Spruce and pine forests are present on the Helan and Daluo Mountains to the west, and the Ziwu and Liupan Mountains to the south, while pine forest occurs on the Yinshan Mountain to the north. All five mountain ranges are located $<500 \mathrm{~km}$ from the study site; thus the alpine forests may be a source of long-distance-transported pollen to the Bahar Nuur pollen record.

Both Pinus bungenna (Haploxylon type Pinus) and Pinus tabalaeformit (Diploxylon type Pinus) are present in those mountains near Ordos Plateau. Pinus 


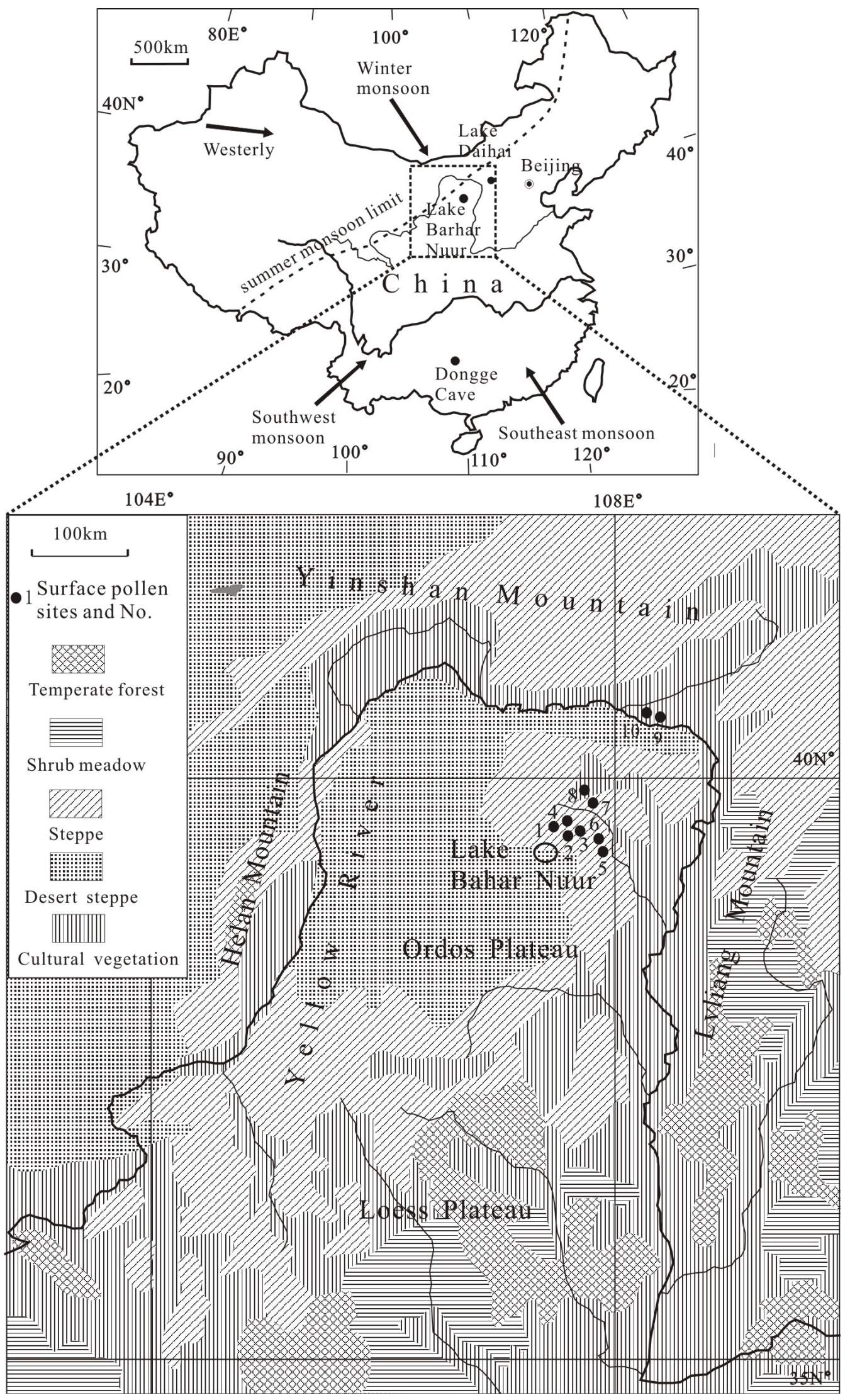

Figure 1. Regional vegetation around the Ordos Plateau showing location of the study sites, surface pollen samples and its relative location within China. 
bungenna typically grow in cold, arid environment at higher elevations, whereas $P i$ nus tabalaeformit tends to occur in mild, wet environment at lower elevations [12].

\section{Methods}

A 530-cm long core was drilled with a gravitational piston corer in 2003 in the central part of Bahar Nuur. Fossil pollen samples were collected at intervals of $\sim 5$ $\mathrm{cm}$ and 100 samples were analyzed. Samples for other analyses (grain size, total organic carbon [TOC], and $\delta^{13} \mathrm{C}$ of organic matter) were collected at $2 \mathrm{~cm}$ intervals. Ten surface soil samples were collected from some 5 lake shores in the Ordos Plateau to provide modern pollen data in order to improve the interpretation of the fossil pollen spectra regarding pollen sources, transport processes, and bioclimatic representation.

We take 20 - 30 gram soil for each sample. Following standard palynological procedures [13], pollen samples were treated with potassium hydroxide, hydrochloric acid, and hydrofluoric acid to remove organic matter, carbonates, and silicates, respectively. One Lycopodium tablet (Lund University, Batch No. 938934) was added per sample in order to calculate pollen concentrations.

Pollen types were identified with the aid of the Moore et al. [14] and Wang et al. [15] identification keys. A total of 48 families or genera were identified. More than 300 pollen grains (not including spores) were counted for each sample and pollen percentages were calculated based on the sum of all terrestrial pollen. A pollen percentage diagram including total pollen concentrations was plotted against depth using Grapher 2.0. Cluster analysis (CONISS) was conducted to delineate pollen zones [16].

The particle size of bulk samples was measured using a Malvern Co. Ltd. Mastersizer 2000 laser diffraction particle size analyzer. Pretreatment of the samples for particle size analysis included adding (1) $\mathrm{H}_{2} \mathrm{O}_{2}$ to remove organic matter, (2) diluted $6 \mathrm{~N} \mathrm{HCl}$ to remove salts, and (3) sodium-hexametaphosphate to disperse the aggregates. The carbonate content was measured with the modified gas evolution method using a Bascomb Calcimeter and total organic matter content was measured with titration method. For organic carbon isotopic analysis $\left(\delta^{13} \mathrm{C}_{\mathrm{org}}\right)$, dried sediment samples were first sieved through meshes of $0.105 \mathrm{~mm}$ to remove undecomposed roots. The sieved fine portion was de-carbonated for 24 hours by adding $10 \% \mathrm{HCl}$ and by repeatedly rinsing with distilled water (until $\mathrm{pH} \approx 7$ ). The samples were dried at $50^{\circ} \mathrm{C}$ for isotopic analyses. The prepared samples were combusted to produce $\mathrm{CO}_{2}$. The combustion-produced $\mathrm{CO}_{2}$ was trapped in a cold finger of liquid $\mathrm{N}_{2}$ and then bathed in a trap of $-75^{\circ} \mathrm{C}$ to gather pure $\mathrm{CO}_{2}$ [17].

Fifteen bulk sediment samples were submitted to Beta Analytic Inc. and the NSF AMS Facility at the University of Arizona for AMS ${ }^{14} \mathrm{C}$ dating.

\section{Results}

\subsection{Modern Pollen Data}

Tree pollen includes Pinus, Quercus, Cupressus, Ulmus, Betula, and others. Me- 
sophilous herb pollen includes Compositate, Artemisia, Gramineae, Urticaceae, Polygonum, Liliaceae, Leguminosae, and others. Xeromorphic herb pollen includes Nitraria, Zygophyllaceae, Ephedra, Chenopodiaceae and others. Wetland plant pollen includes Typhaceae, Cyperaceae, Plantago and Sparganiaceae. Shrub pollen includes Elaeagnaceae and Rosaceae (Figure 2).

All modern pollen samples contain relatively high percentages of Haploxylon type Pinus pollen and Diploxylon type Pinus pollen, ranging between $\sim 10 \%$ and $\sim 40 \%$ (Figure 3), although, except for a few pine trees planted in this area, there are no pine forests or pine-associated forest-steppes occurring around the lake or in the watershed. The Pinus pollen has most likley probably been transported by wind from the pine-dominated forest-steppes. It is apparent that the Pinus pollen is over-represented in the pollen spectra, confirming the widely-reported over-representation of Pinus pollen in the semi-arid and arid regions of China and Mongolia [18].

Despite the dominance of grasses in the steppes and desert steppes in the Ordos Plateau, Gramineae pollen percentages are rather low, being below $10 \%$ in seven of the ten surface samples, confirming the under-representation of Gramineae pollen previously reported for the Mongolian steppes [18]. Chenopodiaceae and Artemisia pollen percentages are relatively high. Although there are only scattered Quercus trees but no Quercus forest in the Ordos Plateau, Quercus accounts for most of the broadleaf tree pollen.

\subsection{Lithology and Chronology}

The basal section ( $530-435 \mathrm{~cm}$ ) of the core is slightly dark sand. It is overlain by lacustrine sediments consisting of a dark clay $(435-350 \mathrm{~cm})$, a slightly dark silty-clay $(350-300 \mathrm{~cm})$, la Carbonate-enriched and clayed varves $(300-230 \mathrm{~cm})$, and a reddish-brown silty-clay $(230-80 \mathrm{~cm})$. The top $80 \mathrm{~cm}$ is grayish sand (Figure 3).

Fifteen AMS ${ }^{14} \mathrm{C}$ dates were obtained (Table 1). All material is bulk. The basal sand $(435-530 \mathrm{~cm})$ was dated at three depths with ${ }^{14} \mathrm{C}$ ages from $13,910 \pm 70$ to

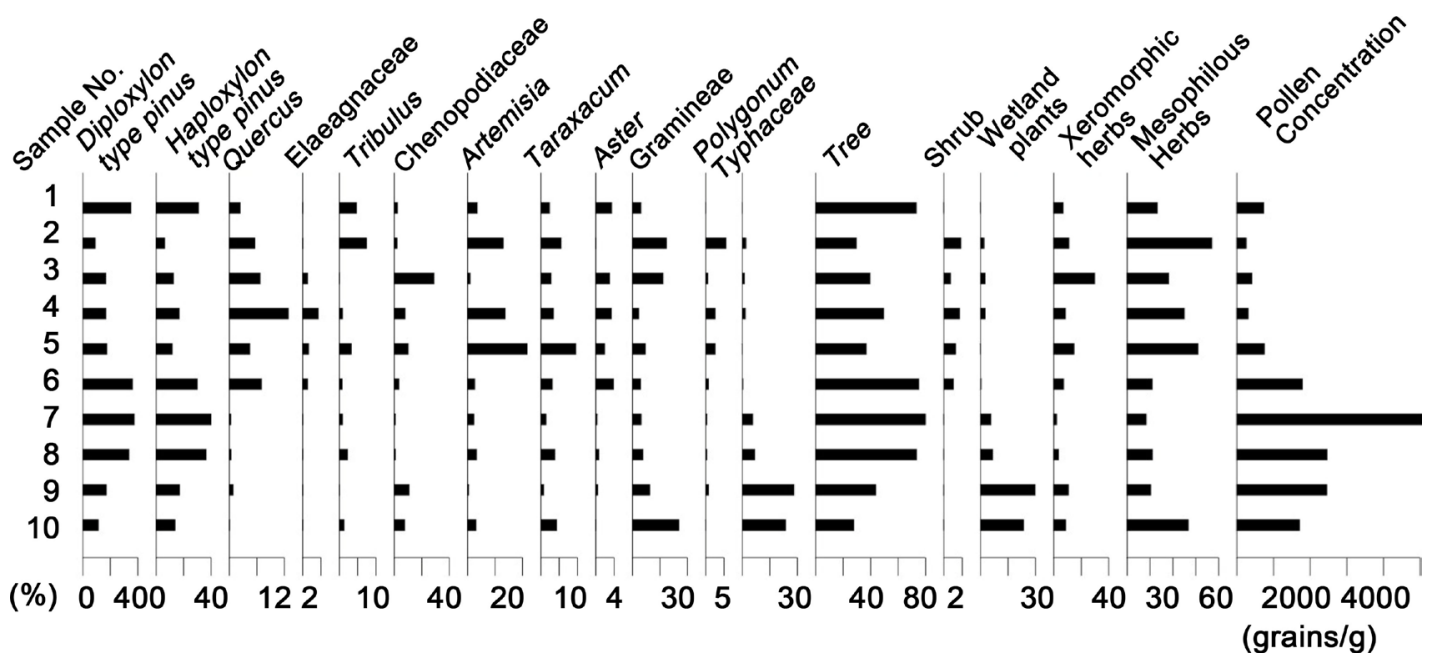

Figure 2. Pollen percentage diagram of 10 surface samples collected from lake shores in $0-5 \mathrm{~m}$ depth. 


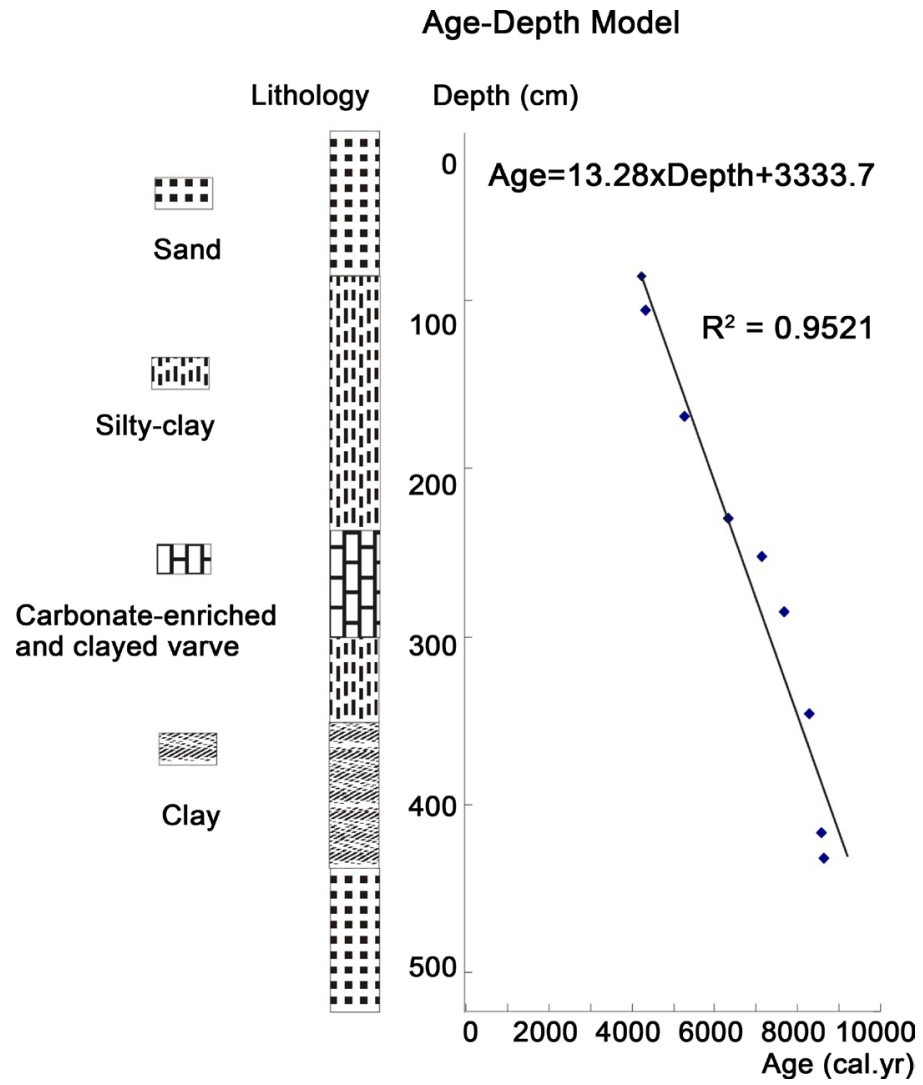

Figure 3. Lithology and Depth-Age model.

Table 1. AMS dates and the relevant information (AA samples were dated by the NSF AMS Facility at the University of Arizona; Beta samples were dated by Beta Analytic, Inc., USA).

\begin{tabular}{|c|c|c|c|c|c|c|}
\hline Lab No. & Field No. & $\begin{array}{c}\text { Depth } \\
(\mathrm{cm})\end{array}$ & $\begin{array}{c}{ }^{13} \mathrm{C} /{ }^{12} \mathrm{C} \\
(\% \mathrm{o})\end{array}$ & AMS dates & Cal. Age B.P. & $\begin{array}{l}\text { subtract } 1950 \\
\text { yr (True age) }\end{array}$ \\
\hline Beta-181620 & $\mathrm{BN} 16$ & 81 & -23.8 & $5440 \pm 40$ & $6251 \pm 34$ & $4301 \pm 34$ \\
\hline AA56715 & $\mathrm{BN} 15$ & 103 & -8.5 & $5549 \pm 42$ & $6352 \pm 38$ & $4402 \pm 38$ \\
\hline AA56714 & BN14 & 133 & -12 & $6538 \pm 44$ & $7461 \pm 29$ & $5511 \pm 29$ \\
\hline Beta-181620 & $\mathrm{BN} 13$ & 167 & -24.2 & $6340 \pm 40$ & $7268 \pm 48$ & $5318 \pm 48$ \\
\hline Beta-181619 & BN11 & 227 & -24.2 & $7500 \pm 40$ & $8306 \pm 63$ & $6356 \pm 63$ \\
\hline Beta-171831 & BN10 & 250 & -25.7 & $8130 \pm 50$ & $9090 \pm 61$ & $7140 \pm 61$ \\
\hline AA51969 & BN9 & 283 & -13.1 & $8631 \pm 52$ & $9608 \pm 53$ & $7658 \pm 53$ \\
\hline Beta- 171830 & BN8 & 327 & -24.9 & $7960 \pm 40$ & $8839 \pm 106$ & $6889 \pm 106$ \\
\hline AA51968 & BN7 & 345 & -12.4 & $9038 \pm 57$ & $10,208 \pm 33$ & $8258 \pm 33$ \\
\hline Beta-171829 & BN6 & 385 & -24.8 & $8850 \pm 40$ & $9973 \pm 133$ & $8023 \pm 133$ \\
\hline AA51967 & BN5 & 415 & -11 & $9303 \pm 64$ & $10,489 \pm 95$ & $8539 \pm 95$ \\
\hline AA51966 & $\mathrm{BN} 4$ & 431 & -10.2 & $9338 \pm 57$ & $10,553 \pm 86$ & $8603 \pm 86$ \\
\hline Beta- 171828 & BN3 & 487 & -23.8 & $13,910 \pm 70$ & $17,162 \pm 208$ & $15,212 \pm 208$ \\
\hline AA51965 & $\mathrm{BN} 2$ & 506 & -3.2 & $27,850 \pm 280$ & $32,405 \pm 340$ & $30,455 \pm 340$ \\
\hline AA51964 & BN1 & 527 & -6.5 & $24,290 \pm 537$ & $29,133 \pm 648$ & $27,183 \pm 648$ \\
\hline
\end{tabular}


$27,850 \pm 280{ }^{14} \mathrm{C}$ yr BP. The large age difference between $487 \mathrm{~cm}\left(13,910 \pm 70{ }^{14} \mathrm{C}\right.$ $\mathrm{yr} \mathrm{BP})$ and $506 \mathrm{~cm}\left(27,850 \pm 280{ }^{14} \mathrm{C}\right.$ yr BP) perhaps results from a depositional hiatus or an erosion event during the last glacial maximum. The age reversal between $506 \mathrm{~cm}\left(27,850 \pm 280{ }^{14} \mathrm{C}\right.$ yr BP $)$ and $527 \mathrm{~cm}\left(24,290 \pm 537{ }^{14} \mathrm{C}\right.$ yr BP $)$ may be a result of the upward movement of sediments, either by sand reactivation or bioturbation. Three slight age reversals occur at $133 \mathrm{~cm}, 327 \mathrm{~cm}$, and 385 $\mathrm{cm}$.

A carbon reservoir age could not be directly calculated. Because the top $80 \mathrm{~cm}$ of the core consists of aeolian transported sand, the common linear regression method could not be used, while the complete lack of terrestrial material eliminated the possibility of employing the comparison method. Therefore, the AMS dates were corrected by applying previously published regional data, which show that the radiocarbon reservoir in the arid-semiarid western China is generally high, though variable [19] [20] [21], with values ranging from $1000-2000 \mathrm{yr}$ in the Ordos plateau [19] and values ranging from 2590 to $4340 \mathrm{yr}$ in the Qaidam Basin of the Tibetan Plateau [22]. Closer to the site, we recently obtained a radiocarbon reservoir of 1950 years from Qigai Nuur, only $1 \mathrm{~km}$ from Bahar Nuur. This is consistent with reservoir values of $2000 \mathrm{yr}$ from Daihai [23] about 200 $\mathrm{km}$ to the north, and $1935 \mathrm{yr}$ from Lake Gouchi about $100 \mathrm{~km}$ to the west [24]. Accodingly, assuming a reservoir effect of $1950 \mathrm{yr}$ for the Bahar Nuur, we subtracted $1950 \mathrm{yr}$ from all the AMS dates obtained from the core. All corrected AMS dates were converted into calibrated ages using the INTCAL program [25], and a linear regression, best-fit calibrated age-depth model was constructed after eliminating the three reversed age data. A linear relationship $\left(R^{2}=0.9521\right)$ exists among the 9 AMS dates within the lacustrine section of the core $(435-80 \mathrm{~cm})$, suggesting that the age model adequately captures the chronology. The linear relationship is also supported by the relatively uniform particle size distribution within the section of lacustrine sediments. The average sediment rate for this section is $0.081 \mathrm{~cm} / \mathrm{yr}$.

\subsection{Pollen Stratigraphy and Associated Proxy Data}

Because pollen is absent or rare in the sand intervals at the bottom and at the top of the core, fossil pollen data are only presented for the lacustrine section from $435-80 \mathrm{~cm}$. Seven pollen assemblage zones, including the top and bottom nonpolleniferous zones, are recognized for the core, based on visual inspection and CONISS results (Figure 4).

Zone 1 (530 - $435 \mathrm{~cm}$; before $8.6 \mathrm{ka} \mathrm{BP})$, corresponding with the basal sand, contains little or no pollen. Here the TOC is less than $2 \%$ and the $\delta^{13} \mathrm{C}$ of organic matter is relatively low (mostly $-24 \%$ to $-26 \%$ ). Carbonate values are $<8 \%$.

Zone $2(435-350 \mathrm{~cm} ; 8.6-8.2 \mathrm{ka} \mathrm{BP})$, which roughly corresponds with the clay unit, is characterized by low pollen percentages for Pinus pollen and high percentages of Gramineae. Pinus pollen are $<80 \%$. Quercus is $<8 \%$. Chenopodiaceae is high with average value 5\%. Ephdra fluctuate within $1 \%-5 \%$. Gramineae pollen percentage peaks in this zone. Pollen concentration is less than 20,000 


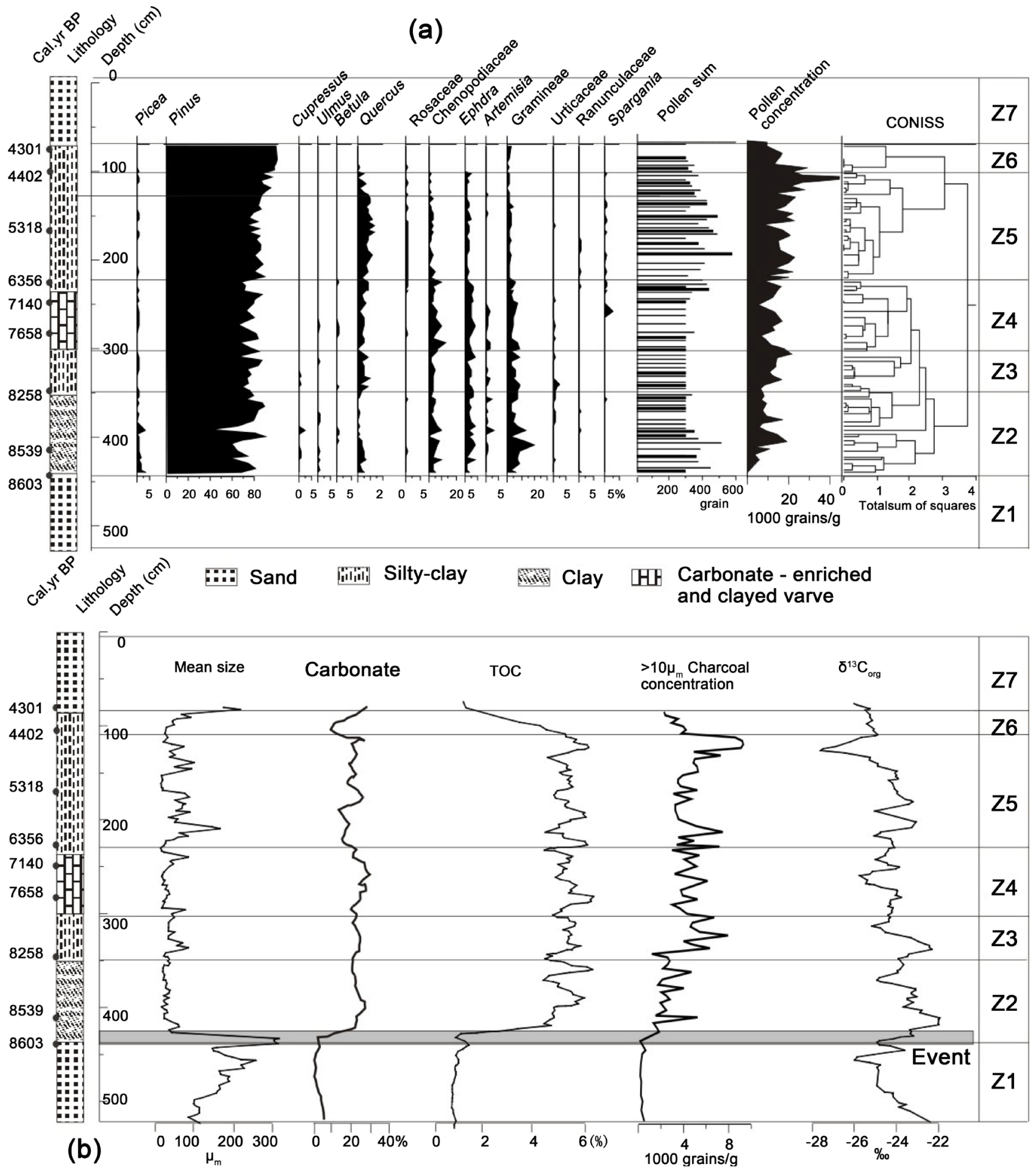

Figure 4. (a) Pollen percentage diagram from Bahar Nuur. (b) Curves for other proxy parameters from the Bahar Nuur core (data from [17]).

grains/g. TOC increases abruptly to $4 \%-6 \%$ and remains high throughout the lacustrine section. Mean grain size is uniformly low $(<50 \mu \mathrm{m})$ in this clay unit, whereas $\delta^{13} \mathrm{C}_{\text {org }}$ is generally high $(-22 \%$ o to $-24 \%$ ). Carbonate increases sharply to $20 \%-30 \%$.

Zone 3 (350 - $300 \mathrm{~cm} ; 8.2$ - $7.8 \mathrm{ka} \mathrm{BP})$, corresponding with the silty-clay unit, 
is marked by a distinct increase in Quercus pollen at the base. The pollen percentages of Ephedra remain high, while the pollen percentage of Pinus increases slightly. Quercus fluctuate within 2\% - 10\%. Chenopodiaceae is around $3 \%-4 \%$. Ephdra is about 2\% - 3\%, Gramineae pollen percentage $<10 \%$. Pollen concentration fluctuates within $8000-22,000$ grains/g. Mean grain size increases slightly and Carbonate remains high.

Zone $4(350-220 \mathrm{~cm} ; 7.8-6.3 \mathrm{ka} \mathrm{BP})$, which roughly corresponds with the laminated calcareous clay, is marked by stable pollen percentages. Pinus pollen values are around $75 \%$ - 80\%. Quercus fluctuate within 2\% - 10\%. Chenopodiaceae and Ephdra reach their highest values, while Gramineae values decline slightly. Pollen concentration fluctuates within 8000 - 18,000 grains/g. Mean grain size is very small and carbonate is high. Charcoal concentration is around 4000 6000 grains $/ g$. $\delta^{13} \mathrm{C}_{\text {org }}$ values fluctuate in this zone but on the whole decline slightly.

Zone $5(220-100 \mathrm{~cm} ; 6.3-4.4 \mathrm{ka} \mathrm{BP})$, corresponding with the silty-clay, is characterized by increasing pollen percentages of Pinus, while Quercus pollen reaches its maximum abundance. Rosaceae increases, reaching $2 \%$. The steppe component (Chenopodiaceae, Ephdra, Atermisia and Gramineae) pollen percentage decline while wetland taxa (i.e. Spargania) increase. Pollen concentration values are highest in this zone. Charcoal concentration fluctuates within 4000 - 10,000 grains/g. Mean grain size is slightly larger than in the previous zone but is variable. $\delta^{13} \mathrm{C}_{\text {org }}$ drops sharply near the top of this zone while TOC increases. Carbonate fluctuates in this zone but remains relatively high.

Zone $6(100-80 \mathrm{~cm} ; 4.4-4.3 \mathrm{ka} \mathrm{BP})$ roughly corresponds with the silty-clay. Pinus pollen increases to maximum percentages while almost all other pollen taxa abruptly decrease or disappear, with only Gramineae remaining stable. Pollen concentrations also decline sharply in this zone. Mean grain size increases dramatically while TOC decreases sharply. Charcoal concentration declines. $\delta^{13} \mathrm{C}_{\text {org }}$ recovers from the crash but remains low and Carbonate is low.

Zone 7 ( 80 - $0 \mathrm{~cm}$; after $4.3 \mathrm{ka} \mathrm{BP})$, corresponds with the top eolian sand unit. Pollen grains were not plotted due to their scarcity.

\section{Regional Comparison}

\subsection{Early-Holocene}

The non-polleniferous sand deposited before $8.6 \mathrm{ka} \mathrm{BP}$ suggests that no lake existed and that the vegetation was locally very sparse before $8.6 \mathrm{ka}$ BP. The climate was probably dry, or the dry lakebed was not conducive to pollen deposition and preservation. Although an early Holocene climate optimum was documented for Midiwan [6] during 11.5 - $8.3 \mathrm{ka}$ BP following a humid phase from 16.3 and $8.87 \mathrm{ka}$ BP in Yanhaizhi [8], a number of studies have shown that along the northern margin of the East Asian monsoon precipitation was low in the early Holocene, increasing after $8 \mathrm{ka}$ BP [4] [26].

At $\sim 8.6 \mathrm{ka} \mathrm{BP}$, the core lithology changes from sand to clay, and pollen becomes much more abundant. Charcoal concentrations also increase significant- 
ly. The abrupt onset of lacustrine sedimentation suggests that the lake formed rather quickly. This indicates a rapid climatic change towards wetter conditions, and denser vegetation. This is supported by dramatic increases in TOC and a sharp decrease in mean grain size.

\subsection{Middle Holocene}

The presence of a lake from $\sim 8.6$ to $4.3 \mathrm{ka} \mathrm{BP}$, as indicated by contonious lacustrine sedimentation, implies that the mid-Holocene was a more humid than the present. Between $\sim 8.6$ and $\sim 7.8$ ka BP (Zone 2 and Zone 3), during the early phase of this wet period the vegetation around Bahar Nuur was a grass dominated steppe with some xerophytic herbs and shrubs such as Chenopodiaceae and Ephedra.

From $\sim 7.8$ to $\sim 6.3 \mathrm{ka} \mathrm{BP}$ (Zone 4 ), although steppe vegetation still dominates, many other types of plants appear and persist. This sediment consists of alternating varves, composed of black (organic matter-rich) and white (carbonate) couplets. The formation of varves requires strikingly different seasonal conditions and lake depth deep enough to permit stable bottom water [27]. The white couplet suggests that the summer temperatures were high enough to drive evaporation-generated carbonate deposition. The fine particle size, indicating high lake levels, suggests that warm and humid conditions prevailed during this period.

Quercus (Quercus liaotungensis) populations reach their greatest abundance between $\sim 6.3$ and $\sim 4.4 \mathrm{ka}$ BP (Zone 5), indicating humid conditions. It is more humid than zone 4 . The slight but sustained increase in Rosaceae pollen indicats that shrubs such as Caragana also increased in abundance. The increase in trees and shrubs occurred at the expense of the xerophytic plants, as indicated by a concomitant decrease in the pollen percentages of Gramineae, Chenopodiaceae, and Ephedra. The general decrease in $\delta^{13} \mathrm{C}_{\text {org }}$ values from zone 2 to zone 5 also supports this scenario, as $\mathrm{C} 3$ plants (including most trees) have much lower (i.e., more negative) $\delta^{13} \mathrm{C}$ values than $\mathrm{C} 4$ plants (including many desert grasses and herbs). As a result, the vegetation reached its highest density during this period, as evidenced by maximum pollen concentration values for this zone. High charcoal concentrations in this zone are also consistent with maximum biomass, which provide more fuels for fires. The increase in wetland plants such as $S p a r$ gania also indicate humid environment. The pollen evidence indicates that the Holocene Optimum occurred in this area during Zone5 ( 6.3 to $\sim 4.4 \mathrm{ka} \mathrm{BP}$ ).

\subsection{Late Holocene}

Quercus pollen declined abruptly after $\sim 4.4 \mathrm{ka} \mathrm{BP}$, as did charcoal concentrations and pollen for most other taxa. These changes signify a return to harsher climate conditions, leading to a more open vegetative landscape. The change from lacustrine sedimentation to deposition of eolian sand after $\sim 4.3 \mathrm{ka}$ BP indicates that the lake either dried up or became ephemeral during the late Holocene, thereby ending the pollen record. Most records from area dominated by 
the Asian monsoon show markedly lower effective moisture in late Holocene due to the weak summer monsoon [28].

\subsection{Regional Comparison of Mid-Holocene Climate Changes}

To put the reconstructed vegetation history of Bahar Nuur in a regional perspective, we reviewed other records in or near the Ordos Plateau. At the Dadiwan and Sujiawan sections in the western part of the Chinese Loess Plateau, deciduous forest of high density and diversity dominated by oaks and birch that existed from 6.56 to $5.79 \mathrm{ka}{ }^{14} \mathrm{C}$ yr BP were replaced by pine-dominated forest-steppe during 5.79 - $4.95 \mathrm{ka} \mathrm{BP}\left({ }^{14} \mathrm{C}\right.$ age $)$, then degraded into elm-dominated sparse forest-steppe during $4.954 \mathrm{ka} B \mathrm{BP}\left({ }^{14} \mathrm{C}\right.$ age $)$. The vegetation and climate conditions deteriorated after $4 \mathrm{kaBP}\left({ }^{14} \mathrm{C}\right.$ age $)$, as forest was replaced by steppe. Thus, the period of maximum warmth and humidity prevailed between 6.56 and $4.95 \mathrm{ka} \mathrm{BP}\left({ }^{14} \mathrm{C}\right.$ age) in the western Loess Plateau [29]. However, the pollenbased proxy records from Midiwan [5] [6] suggest that a desert-grassland interval occurred between 7.5 and $4.5 \mathrm{ka}\left({ }^{14} \mathrm{C}\right.$ age $)$ with a relatively warm climate in Ordos Plateau. Corresponding lithology is silty peat with a large amount of plant residues and freshwater fossil mollusks [6] which indicates humid environment. Furthermore, organic carbon content is relatively high compared with next zone. Although pollen concentration is low, Chenopodiaceae and Ephedra pollens are much less than Artemsia and Composite pollens. At the TYG section to the southeast of Bahar Nuur, a warm and humid Holocene Optimum occurred during between $\sim 7.7$ and $\sim 5.6 \mathrm{ka} \mathrm{BP}$, as inferred from dune building as well as pollen assemblages [30]. Our data from Bahar Nuur show lush mid-Holocene vegetation in the central Ordos Plateau, with the most mesic conditions occurring around $6.3 \sim 4.4 \mathrm{ka} \mathrm{BP}$. To the west, records from Lake Yanhaizi suggest that the mid-Holocene (8.0 $4.3 \mathrm{ka} \mathrm{BP})$ was arid in Inner Mongolia, with low TOC and high sand sediment [9]. Further to the northeast, pollen records and pollenbased paleoclimatic reconstruction from Daihai in Inner Mongolia suggest that the mean July temperature was $2^{\circ} \mathrm{C} \sim 3^{\circ} \mathrm{C}$ higher and the precipitation was $100 \sim$ $180 \mathrm{~mm}$ higher than present from $\sim 7.9 \sim 4.45 \mathrm{ka}$ BP [26]. At Diajiaohaizi in Daiqingshan, pollen records suggest a generally warm and humid mid-Holocene. Temperature was $1^{\circ} \mathrm{C}-2^{\circ} \mathrm{C}$ higher than today and precipitation was 150 $200 \mathrm{~mm}$ more than today during $6.9 \sim 6.3 \mathrm{ka}$ BP [31].

To date, only the Yanhaizi site clearly documents a dry mid-Holocene, contradicting records from most other sites in the Ordos Plateau and Chinese Loess Plateau. Since lakes Yanhaizi, Barhar Nuur and Diahai are located in the northwestern margin of Asian monsoon, precipitation levels in this area are closely related to variations in the strength of Asian summer monsoon. We compare our records with Northern Hemisphere insolation and the $\delta^{18} \mathrm{O}$ record from Dongge cave, which is an excellent proxy for Asian monsoon strength.

The Asian monsoon is strong before $\sim 4.4 \mathrm{ka} \mathrm{BP}$ and weak after $\sim 4 \mathrm{ka} \mathrm{BP}$ as indicated by the Dongge cave $\delta^{18} \mathrm{O}$ proxy record, corresponding to lush vegetation from 6.3 - $4.4 \mathrm{ka} \mathrm{BP}$ and sparse vegetation after $\sim 4.2 \mathrm{ka}$ BP at both Barhar 
Nuur and Daihai. Corresponding to the dry event that occurred at $\sim 4.2 \mathrm{ka} B \mathrm{BP}$, vegetation deteriorated sharply in both Barhar Nuur and Daihai while a weak Asian monsoon event occurred in Dongge cave. This severe climatic deterioration was synchronous with a climatic event during the late third millennium BC identified in many Northern Hemisphere sites [32], marking the ending of Holocene Optimum. Wu and Liu [32] suggest that this climatic change may have played a very important role in the collapse of Neolithic cultures around the Central Plain of China. A humid mid-Holocene can be inferred from Figure 5, as the Asian monsoon was relatively strong, and broadleaves tree pollen and pollen concentration are high in both Barhar Nuur and Daihai during $6.3 \sim 4.4$ ka BP, reflecting denser vegetation and a humid mid-Holocene. This humid mid-Holocene is also echoed in Qinghai Lake which is also located in north margin of Asian monsoon. According to multi-proxy analysis, Shen presents a warm and wet period between 14.1 ka BP and 4.5 ka BP in Qinghai Lake area. After that, the climate gradually became colder and drier [20].

\subsection{Discussion on Forcing Mechanisms}

It has been suggested that variation in the strength of the East Asian monsoon is controlled by changes in summer solar radiation in the Northern Hemisphere on glacial-interglacial timescales [33]. Holocene solar insolation peaked at $\sim 10 \mathrm{ka}$ BP in northern semi-sphere [34]. However, the existence of substantial ice

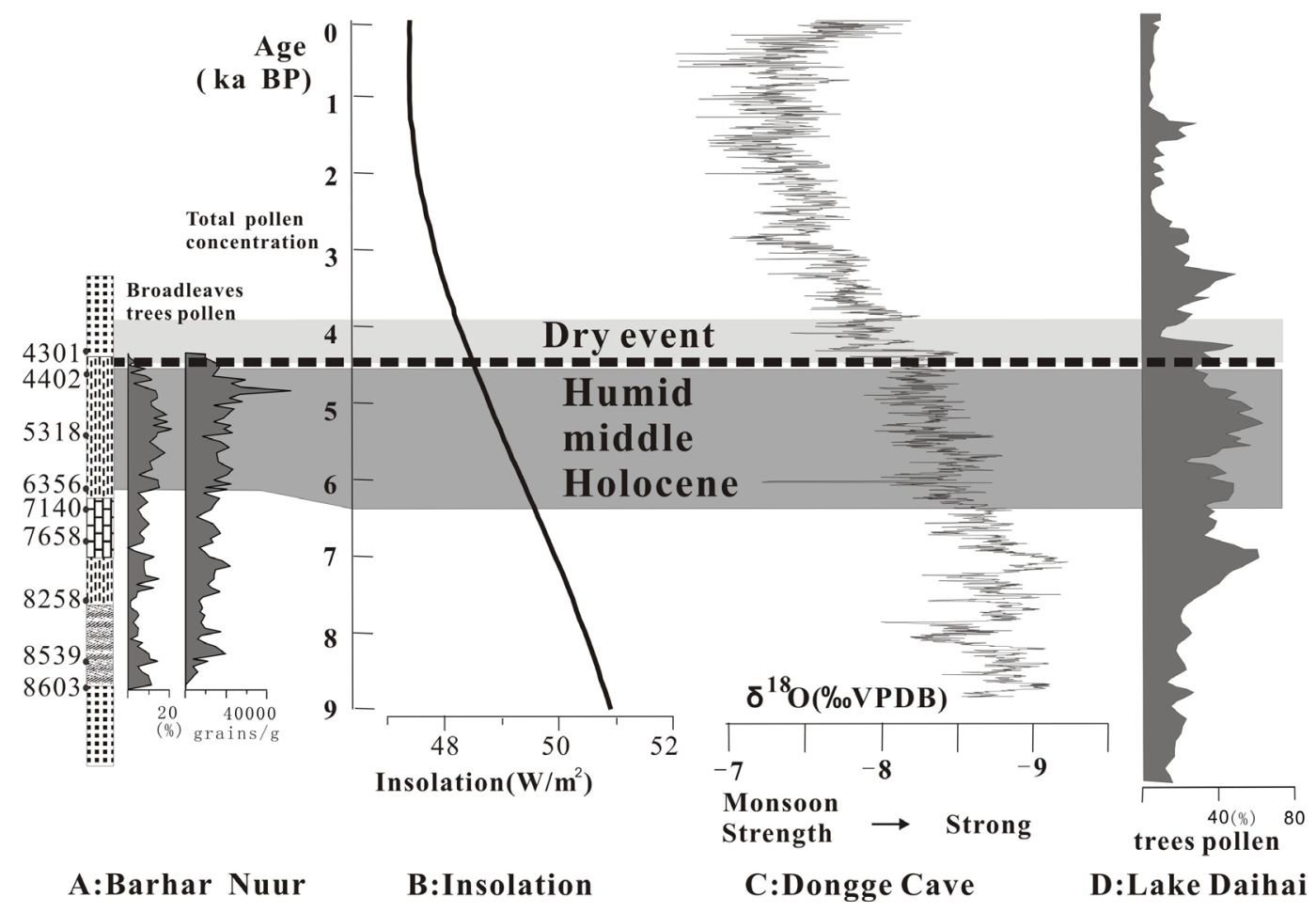

Figure 5. Holocene climate comparison. A: lithology and pollen data in Barhar Nuur; B: Solar insolation at $40^{\circ} \mathrm{N}$ (Berger and Loutre, 1991) [34]; C: Dongge cave speleothem (Wang et al., 2005) [35]; D: Daihai trees pollen [26]. 
masses in the northern high latitudes and remnant ice sheets may have hampered the Asian continent from warming up during the early Holocene, resulting in a cold, dry early Holocene in the Ordos Plateau. Oceans need much more energy to warm up than the land. Tropical Holocene SST increased steadily from $\sim 10 \mathrm{ka}$ to $\sim 6 \mathrm{ka} \mathrm{BP}[36]$. According to the $\delta^{18} \mathrm{O}$ proxy record from Dongge cave, the Asian monsoon which was relatively strong until about $4.4 \mathrm{ka}$ BP, would have kept monsoon precipitation levels high during mid-Holocene, particularly given the enhanced evaporation on west Pasific which effectively injected more water vapor into the East Asian monsoon system during 10 ka to $\sim 6 \mathrm{ka} \mathrm{BP} \mathrm{[3].}$ The warmer and wetter climate associated with the Holocene Climatic Optimum lead to denser vegetation cover, which might have further promoted the Optimum through the feedback mechanism related to the air-vegetation-soil coupling under the denser vegetated wetter conditions [3]. It is plausible that the humid mid-Holocene is a lagged response to Asian monsoon and peak summer insolation in the Northern Hemisphere. When summer insolation largely decreased after $6 \mathrm{ka}$ BP and Asian monsoon was weak in late Holocene, it results in a dry late Holocene in the Ordos Plateau.

The dry mid-Holocene record from Yanhaizi Lake is inconsistent with the wet mid-Holocene extensively documented in other regional sites. The effective soil moisture during the mid-Holocene was probably low in Yanhaizi area where the increase in evaporation resulting from rising temperatures might have exceeded the overall increase in precipitation, leading to an increase in climatic aridity and a decrease in effective soil moisture. However, we find no evidence for a dry mid-Holocene in the Ordos Plateau. More work is required to understand these regional differences.

\section{Conclusion}

We analyze 100 pollen samples from Bahar Nuur Lake in order to reconstruct the history of Holocene environment change in the Ordos Plateau, with a chronology based on 15 AMS dates. Before $8.6 \mathrm{ka} \mathrm{BP}$, the climate was probably dry resulting in a sparsely vegetated environment. From $8.6-7.8 \mathrm{ka}$ BP, the site was a grass-dominated arid steppe. From $7.8-6.3 \mathrm{ka}$ BP, the climate was warm and humid resulting in a steppe. From $6.3-4.4 \mathrm{ka}$ BP, climate was probably warm and humid, with a sharp increase in forest taxa, identifying this interval as the Holocene Climatic Optimum. From 4.4 - 4.3 ka BP, the climate dried significantly, with the site becoming an arid steppe and after $\sim 4.3 \mathrm{ka} \mathrm{BP}$, climate became much drier, with the lake transforming into desert steppe. Regional records generally support the view of a humid mid-Holocene prevailed in the Ordos Plateau. We suggest that the mid-Holocene Climatic Optimum occurred in the Ordos Plateau as a delayed response to high insolation in the Northern Hemisphere, as transferred by the Asian monsoon.

\section{Acknowledgements}

The authors thank: Chinese Nature Science Foundation for the grant (No.403- 
31012); US. National Science Foundation grants (ATM-0402475); Guizhou Provincial Science and Technology for the grant (2013-2273); Guizhou Provincial Education Department for excellent talent foundation (2013-151). Thanks to Prof. Kam-biu Liu, Prof. Zhao-dong Feng, Prof. Xinqing Lee P, Prof. Yu-zhen $\mathrm{Ma}$. They gave much instruction.

\section{References}

[1] Wanner, H., Beer, J., Butikofer, J., Crowley, T.J. and Cubasch, U. (2008) Mid to Late Holocene Climate Change: An Overview. Quaternary Science Reviews, 27, 17911828. https://doi.org/10.1016/j.quascirev.2008.06.013

[2] Broecker, W.S. (1997) Future Directions of Paleoclimate Research. Quaternary Science Reviews, 16, 821-825. https://doi.org/10.1016/S0277-3791(97)00050-4

[3] Feng, Z., An, C. and Wang, H. (2006) Holocene Climatic and Environmental Changes in the Arid and Semi-Arid Areas of China: A Review. The Holocene, 16, 119-130. https://doi.org/10.1191/0959683606hl912xx

[4] Zhao, Y., Yu, Z. and Chen, F. (2009) Spatial and Temporal Patterns of Holocene Vegetation and Climate Changes in Arid and Semi-Arid China. Quaternary International, 194, 6-18. https://doi.org/10.1016/j.quaint.2007.12.002

[5] Li, X., Zhou, W., An, Z. and Dong, G. (2000) The Vegetation Record of Monsoon Variations at the Desert Loess Transition Belt for the Last 13 Ka. Acta Botanica Sinica, 42, 868-872. (In Chinese)

[6] Li, X., Zhou, W., An, Z. and Dodson, J. (2003) The Vegetation and Monsoon Variations at the Desert Loess Transition Belt at Midiwan in Northern China for the Last 13 Ka. The Holocene, 13, 779-784. https://doi.org/10.1191/0959683603hl664rr

[7] Zhou, W., Dodson, J. and Head, M.J. (2002) Environmental Variability within the Chinese Desert-Loess Transition Zone over the Last 20,000 Years. The Holocene, 12, 117-122. https://doi.org/10.1191/0959683602hl525rr

[8] Chen, C.T., Lan, H.C., Lou, J.Y., Chen, Y.C., et al. (2003) The Dry Holocene Megathermal in Inner Mongolia. Palaeogeography Palaeoclimatology Palaeoecology, 193, 181-200.

[9] Wang, W. (1990) Climates in Inner Mongolia. Science Press, Beijing. (In Chinese)

[10] Zheng, X. (1992) Salt Lakes in Inner Mongolia. Science Press, Beijing. (In Chinese)

[11] China Vegetation Editorial Board (2001) China Vegetation Map. Science Press, Beijing. (In Chinese)

[12] Ma, Y., Meng, H., Sang, Y., Sun, A., Wu, J. and Wang, W. (2009) Pollen Keys for Identification of Coniferopsida and Compositae Classes under Light Microscopy and Their Ecological Significance. Acta Palaeontologica Sinica, 48, 240-253. (In Chinese)

[13] Faegri, K. and Iversen, J. (1975) Textbook of Pollen Analysis. Munksgaard, Copenhagen.

[14] Moore, P.D., Webb, J.A. and Collinson, M.E. (1991) Pollen Analysis. 2nd Edition, Blackwell Scientific Publications, Oxford.

[15] Wang, F., Qian, N. and Zhan, Y. (1995) Pollen Flora of China. Science Press, Beijing. (In Chinese)

[16] Bennett, K.D. (1996) Determination of the Number of Zones in a Biostratigraphical Sequence. New Phytologist, 132, 155-170. https://doi.org/10.1111/j.1469-8137.1996.tb04521.x 
[17] Guo, L., Feng, Z., Lee, X., Liu, L. and Wang, L. (2007) Holocene Climatic Changes Recorded in Bahar Nuur Lake Core in the Erdos Plateau. China Science Bulletins, 25, 584-590. (In Chinese)

[18] Ma, Y., Liu, K., Feng, Z., Sang, Y. and Wang, W. (2008) A Survey of Modern Pollen and Vegetation along a South-North Transect in Mongolia. Journal of Biogeography, 35, 1512-1532. https://doi.org/10.1111/j.1365-2699.2007.01871.x

[19] Ren, G. (1998) Hard Water Effect $\mathrm{P}^{14} \mathrm{PC}$ Age in Inner Mongolia Lake Sediment. Lake Science, 10, 80-82. (In Chinese)

[20] Shen, J., Liu, X. and Wang, S. (2005) Palaeoclimatic Changes in the Qinghai Lake Area during the Last 18,000 Years. Quaternary International, 136, 131-140. https://doi.org/10.1016/j.quaint.2004.11.014

[21] Morrill, C., Overpeck, J.T., Cole, J.E., Liu, K. and Shen, C. (2006) Holocene Variations in the Asian Monsoon Inferred from the Geochemistry of Lake Sediments in Central Tibet. Quaternary Research, 65, 232-243. https://doi.org/10.1016/j.yqres.2005.02.014

[22] Zhou, A., Chen, F., Wang, Z. and Qiang, M. (2009) Temporal Change of Radiocarbon Reservoir Effect in Sugan Lake, Northwest China during the Late Holocene. Radiocarbon, 51, 529-535. https://doi.org/10.1017/S0033822200055909

[23] Wu, Y.H., Wang, S. and Zhou, L. (2007) Modern Reservoir Age for 14C Dating in Daihai Lake. Quaternary Sciences, 27, 507-510.

[24] Feng, Z., Wang, W., Guo, L. and Hkhosbayar, P.H. (2005) Lacustrine and Eolian Records of Holocene Climate Changes in the Mongolian Plateau: Preliminary Results. Quaternary International, 136, 25-32.

https://doi.org/10.1016/j.quaint.2004.11.005

[25] Stuiver, M., Rimer, P.J. and Bard, E. (1998) INTCAL 98 Radiocarbon Age Calibration, 240000 Cal. Radiocarbon, 40, 1041-1083. https://doi.org/10.1017/S0033822200019123

[26] Xiao, J., Xu, Q. and Toshio, N. (2004) Holocene Vegetation Variation in the Daihai Lake Region of North-Central China: A Direct Indication of the Asian Monsoon Climatic History. Quaternary Science Reviews, 23, 1669-1679. https://doi.org/10.1016/j.quascirev.2004.01.005

[27] Peck, J.A., Khosbayar, P. and Fowell, S.J. (2002) Mid to Late Holocene Climate Change in North Central Mongolia as Recorded in the Sediments of Lake Telmen. Palaeogeography Palaeoclimatology Palaeoecology, 183, 135-153. https://doi.org/10.1016/S0031-0182(01)00465-5

[28] Ulrike, H. (2006) Palaeo-Moisture Evolution in Monsoonal Central Asia during the Last 50,000 Years. Quaternary Science Reviews, 25, 163-178. https://doi.org/10.1016/j.quascirev.2005.02.006

[29] Feng, Z., Tang, L., Wang, H., Ma, Y. and Liu, K. (2006) Holocene Vegetation Variations and the Associated Environmental Changes in the Western Part of the Chinese Loess Plateau. Palaeogeography, Palaeoclimatology, Palaeoecology, 241, 440 456. https://doi.org/10.1016/j.palaeo.2006.04.009

[30] Sun, J., Li, S.H., Han, P. and Chen, Y.Y. (2006) Holocene Environmental Changes in the Central Inner Mongolia, Based on Single-Aliquot-Quartz Optical Dating and Multi-Proxy Study of Dune Sands. Palaeogeography, Palaeoclimatology, Palaeoecology, 233, 51-62. https://doi.org/10.1016/j.palaeo.2005.09.016

[31] Yang, Z. (2001) Reconstruction of Climate and Environment Since the Holocene in Diaojiaohaizi Lake Area, Daqing Mountains, Inner Mongolia. Acta Ecologica Sinica, 21, 538-543. (In Chinese) 
[32] Wu, W. and Liu, T. (2004) Possible Role of the "Holocene Event 3" on the Collapse of Neolithic Cultures around the Central Plain of China. Quaternary International, 117, 153-166. https://doi.org/10.1016/S1040-6182(03)00125-3

[33] An, Z. (2000) The History and Variability of the East Asian Paleomonsoon Climate. Quaternary Science Reviews, 19, 171-187. https://doi.org/10.1016/S0277-3791(99)00060-8

[34] Berger, A. and Loutre, M.F. (1991) Insolation Values for the Climate of the Last 10 Million Years. Quaternary Science Reviews, 10, 297-317. https://doi.org/10.1016/0277-3791(91)90033-Q

[35] Wang, Y., Cheng, H. and Lawrence, E.R. (2005) The Holocene Asian Monsoon: Links to Solar Changes and North Atlantic Climate. Science, 308, 854-857. https://doi.org/10.1126/science.1106296

[36] Kiennast, M., Steinke, S., Stattegge, K. and Calvert, S.E. (2001) Synchronous Tropical South China Sea SST Change and Greenland Warming during Deglaciation. Science, 291, 2131-3134. https://doi.org/10.1126/science.1057131

Submit or recommend next manuscript to OALib Journal and we will provide best service for you:

- Publication frequency: Monthly

- 9 subject areas of science, technology and medicine

- Fair and rigorous peer-review system

- Fast publication process

- Article promotion in various social networking sites (LinkedIn, Facebook, Twitter, etc.)

- Maximum dissemination of your research work

Submit Your Paper Online: Click Here to Submit

Or Contact service@oalib.com 